\title{
BIOLOGICAL ASPECT OF BULLET TUNA Auxis rochei (Risso, 1810) IN THE MAKASSAR STRAIT, WEST SULAWESI, INDONESIA
}

\author{
Wayan Kantun ${ }^{1 *}$, Indra Cahyono ${ }^{1}$, Wayan Suma Arsana ${ }^{2}$ \\ ${ }^{1}$ Marine Technology College of Balik Diwa Makassar, Perintis Kemerdekaan St, Makassar, South Sulawesi, Indonesia \\ ${ }^{2}$ Tomakaka University of Mamuju, West Sulawesi, Indonesia \\ *Corresponding Author, Email: aryakantun@yahoo.co.id
}

\section{ARTICLE INFO}

Received: 2 May 2019

Accepted: 11 August 2019

\section{Keywords:}

Size distribution

Growth pattern

Feeding habit

Gut condition

Auxis rocheii

Mamuju waters

\section{ABSTRACT}

The objectives of the present study were to determine the size distribution, growth pattern, feeding habit and stomach fullness index of bullet tuna Auxis rochei in the Makassar Strait, West Sulawesi. The research was conducted for six months between March and August 2017. Sampling collection was carried out using the handline technique. A total of 2160 fish were caught. Their total length ranged from 15.8 to $28.5 \mathrm{~cm}$ and weight ranged from 52.3 to $366.5 \mathrm{~g}$. The total length of male fish ranged from 18.5 to $28.5 \mathrm{~cm}$ and weight ranged from 77.5 to $366.5 \mathrm{~g}$. The total length of female fish ranged from 15.8 to $27.5 \mathrm{~cm}$ and weight ranged from 52.3 to $328.8 \mathrm{~g}$. The growth pattern of bullet tuna for both male and female fish was classified into a positive allometry $(b>3)$; the type of food found in the fish gut consisted of crustacean ( $12.50 \%$ to $25.64 \%$ ), chepalopods ( 7.32 to $34.80 \%$ ) and unidentified (47.69 to $64.51 \%$ ), respectively. Nonetheless, the predominant food condition was not identified and in the gut there was generally no food present. The stomach fullness index ranged from $1.13 \%$ to $7.18 \%, 3 / 4$ (12.11 to $15.74 \%), 1 / 2$ (12.27 to $23.14 \%$ ) and empty (59.26 to $65.74 \%)$. The length size distribution of male bullet tuna was larger than the female with a positive allometric growth pattern. However, the growth pattern of male and female bullet tuna statistically showed no difference.

Kantun, W., Cahyono, I., Arsana, W.S. (2019): Biological aspect of bullet tuna Auxis rochei (Risso, 1810) in the Makassar Strait, West Sulawesi, Indonesia. Croatian Journal of Fisheries, 77, 118-125. DOI: 10.2478/cjf2019-0013. 


\section{INTRODUCTION}

Bullet tuna Auxis rochei has been a sought-after commodity due to its high economic value on both the domestic and international market. It leads to a high exploitation of wild population of bullet tuna leading to the decline of its stock in the wild. Babana in central Mamuju Regency of West Sulawesi has been known as one of the central producers of bullet tuna in Indonesia. Traditional and modern fishing gear has been applied for fishing activity by the local fishermen in Indonesia. The gillnet and handline are used for catching bullet tuna. Nonetheless, fishing activity is dominated by the hand-line technique.

Several studies on aspects of bullet tuna have been documented in the Makassar Strait. The study on the fishing of bullet tuna was based on time, depth and type of bait (Kantun, 2016), length and weight relationship, reproductive season, growth pattern, feeding ecology (Plandri et al., 2009), feeding habits of bullet tuna Auxis rochei in the southern Tyrrhenian Sea (Mostarda et al., 2007), stocks assessment for tuna fish (Melmambessy, 2010), the parameters of chlorophyll-a, the abundance of phytoplankton and zooplankton, primary production, number of fish catches and feeding habits (Kaswadji et al., 2009), the stock assessment on the potential, pattern and level of utilization in the Flores Sea (Mallawa et al., 2006). Research on tuna in other regions has also been carried out, for instance, the potential and exploitation level of mackerel tuna Euthynnus affinis and frigate tuna Auxis thazard (Piscandika et al., 2012), the relationship and integrated marketing of tuna between two fish landings (Lubis and Pane., 2017), the fishing ground of tuna (Girsang, 2008) and the feeding habits of tuna (Aswir et al., 2004). However, there is no study on biological aspect of bullet tuna carried out in the Makassar Strait, particularly in West Mamuju waters. The study aimed to determine the length size distribution, the growth pattern, feeding habits and the stomach fullness index of bullet tuna in the Makassar Strait, West Sulawesi.

\section{MATERIALS AND METHODS}

\section{Study sites}

This study was conducted in the Makassar Strait, West Mamuju waters. The study site is an administrative part of West Sulawesi province, Indonesia, located between the Islands of Kalimantan (Borneo) and Sulawesi. West Mamuju waters have a typical tropical climate that consists of the dry season and rainy season. There are several fishing activities in the location such as commercial fishing, fishing activity by local people using the gill nets, fish traps and various other types of fishing gear. In addition, the Makassar Strait has become a home for many marine species such as large, small pelagic fish, demersal fish and reef fish.

\section{Fish sampling}

Fish sampling was carried out twelve times for 6 months between March and August 2017 in shallow Fish Aggregating Device (FAD) and deep FADs (Figure 1). Fish sampling was performed using hand-line fishing gear of number 10 and 12 size, deployed in both shallow and deep FAD locations.

\section{Length and weight measurements.}

The captured fish was first placed in the buckets. A ruler with an accuracy of $0.1 \mathrm{~cm}$ was used to measure the fork length of fish. The digital balance with $0.01 \mathrm{~g}$ accuracy (Sartorius Brand) was used to obtain the fish weight.

\section{Stomach observation}

The stomach fullness index of fish sampled was observed by dissecting the stomach of tuna (cardiac, body mid portion and pylorus part) and then the contents were observed, including type of food and the condition of the stomach. A total of 60 fish samples were collected for six months or 10 fish per trip.

\section{Data analysis}

\section{Fish distribution}

Fish size distribution was calculated according to Munira (2010) as follows: (1) by determining the number of classes using the "sturgess law" rule with the formula $\mathrm{K}$ (number of classes) $=1+(3.32 \log n) ;(2)$ by determining the interval (class interval width) with the LK formula (class width) = data range divided by class; ( 3 ) by determining the frequency of each class by entering the length of each sample into the specified class interval.

\section{Growth pattern}

The growth pattern of fish was measured using equation: $\mathrm{W}=\mathrm{aL}^{\mathrm{b}}$ (Effendie, 2002). Note: $\mathrm{W}=$ fish weight $(\mathrm{g}), \mathrm{L}=$ fork length $(\mathrm{cm})$, constants $a$ and $b$, obtained from regression analysis.

\section{Stomach fullness index}

The stomach content of fish was analyzed using Index of Preponderance modified by Biswas (1993) below:

$$
I P=((\text { vi } \times \text { oi })) /\left(\sum(\text { vi } \times \text { oi })\right) \times 100 \%
$$

Notes:

IP: Preponderance Index

vi: Food weight

oi: the frequency of type of food obtained in the stomach.

The stomach fullness observation method was modified from Bapal and Bal (1958) where the fullness level of stomach was 1/4, 2/4, 3/4 and 4/4. 


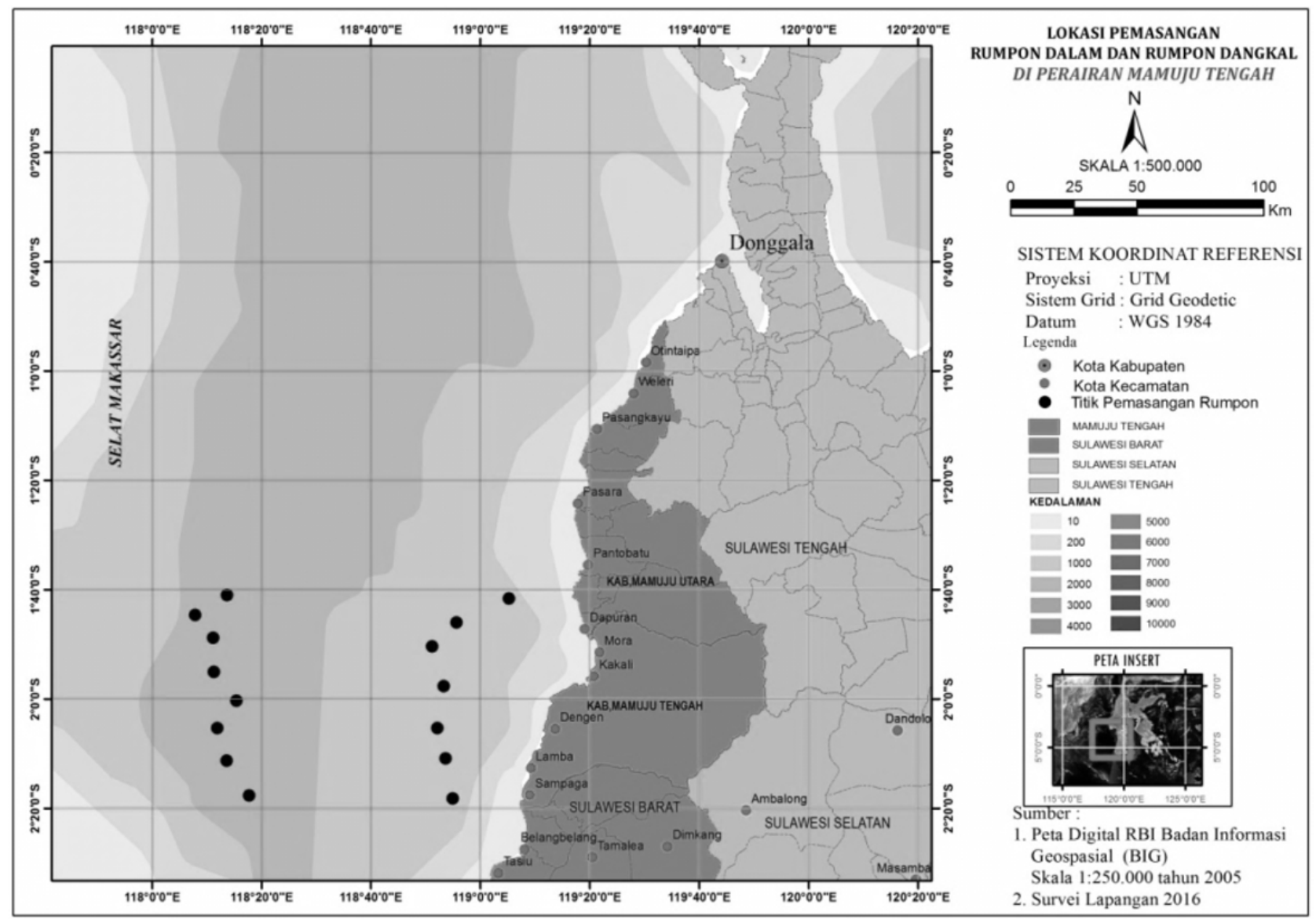

Fig 1. Fishing ground of bullet tuna in the Makassar Strait, West Sulawesi

\section{Statistical analysis}

A t-test was performed using IBM version 22 for the significant difference between the growth patterns of bullet tuna both male and female.

\section{RESULTS}

\section{Size distribution}

A total of 2160 fish was obtained during the study period, consisting of 1216 female and 944 male bullet tuna. The size distribution of female and male bullet tuna varied. The female bullet tuna length and weight distribution ranged from $15.8-27.5 \mathrm{~cm}(23.7 \pm 0.54 \mathrm{~cm})$ and 52.8 $261.3 \mathrm{~g}(190.8 \pm 16.01 \mathrm{~g})$. While male tuna fish length and weight ranged from $18.5-28.5 \mathrm{~cm}(23.6 \pm 0.52 \mathrm{~cm})$ and 77.5-366.5 g (178.4 $\pm 16.02 \mathrm{~g})$, respectively (Figure 2$)$. The frequent size distribution of female bullet tuna based on the class size was $24.0-24.5 \mathrm{~cm}$ or 175 fish (14.39\%), while the male was $23.5-24.0$ or 119 fish (12.69\%).

\section{Growth pattern}

In the present study, the type of growth of bullet tuna is shown in Figure 3. Growth patterns of female bullet tuna

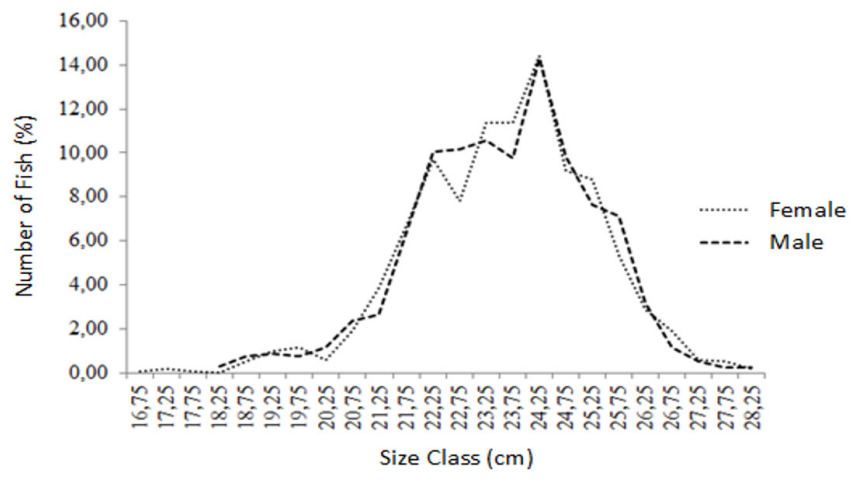

Fig 2. Size distribution of bullet tuna based on sex between March and August 2017

( $n=1216$ fish) obtained $b$ value (3.246 with $r^{2}$ of 0.5142 ) or positive allometric growth $(b>3)$ (Figure $3 A)$. The growth pattern of bullet tuna for male ( $\mathrm{n}=944$ fish) obtained $b$ value (3.4934 with $r^{2}$ of 0.5922 ) or positive allometric growth $(b>3)$, whereas the equation of female and male growth was $\mathrm{W}=0.0059 \mathrm{~L}^{3.246}$ and male $\mathrm{W}=0.0027 \mathrm{~L}^{3.4934}$ (Figure $3 \mathrm{~B}$ ). The t-test analysis suggested that the growth patterns of bullet tuna, both male and female, are not different from positive allometric patterns or greater weight gain compared to length gain. 

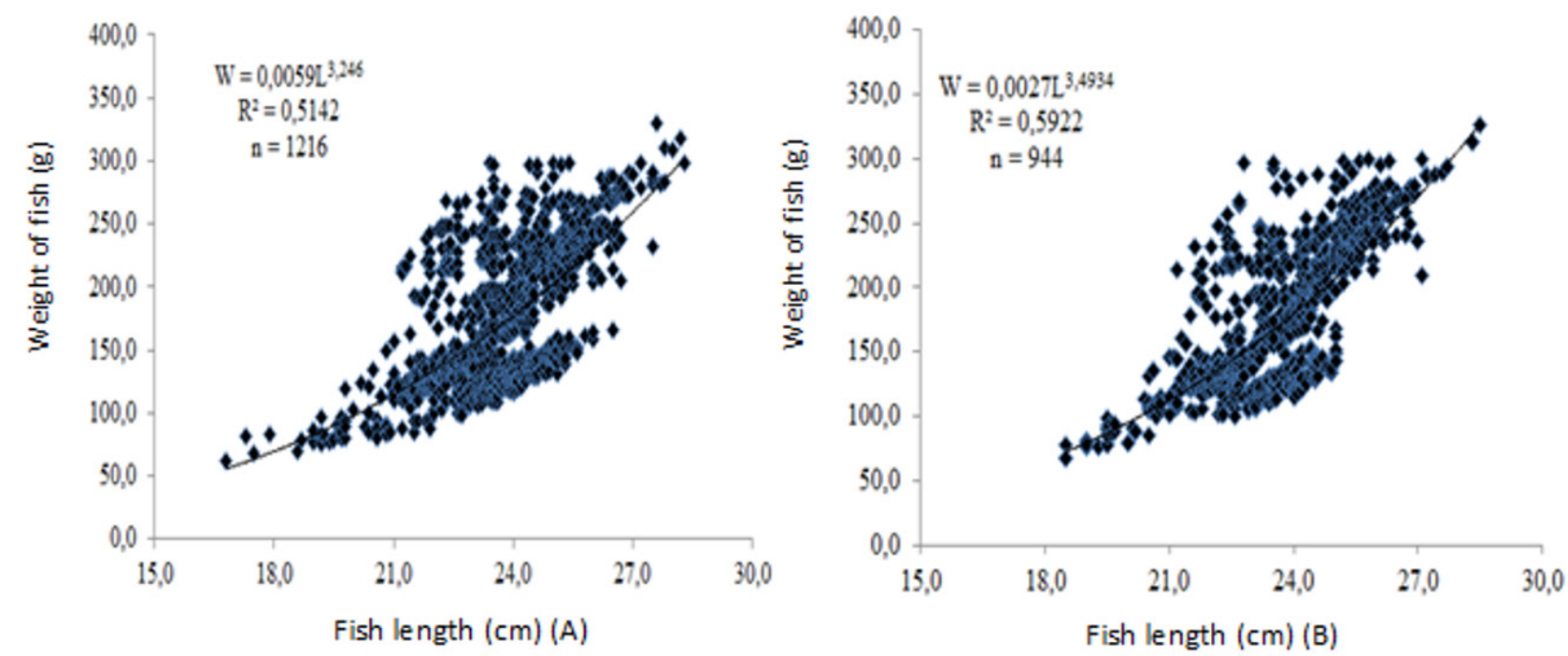

Fig 3. Growth pattern of bullet tuna for female (A) and male (B)

\section{Feeding habit}

In the present study, the type of food found in the bullet tuna gut was dominated by unidentified food (47.69 to $64.51 \%$ or average $\pm 56.1 \%$ ), cephalopods ( 7.32 to $34.80 \%$ or average $\pm 21.06 \%$ ), crustaceans $12.50-25.64 \%$ (average $\pm 19.07 \%$ ) and fish species (14.98 to $22.9 \%$ or average \pm 18.83\%), respectively (Figure 4).

\section{Level of stomach fullness}

The level of stomach fullness of bullet tuna caught at FADs ranged from 59.26 to $65.74 \%$. The lowest condition was 1.13-7.18\% (Figure 5).

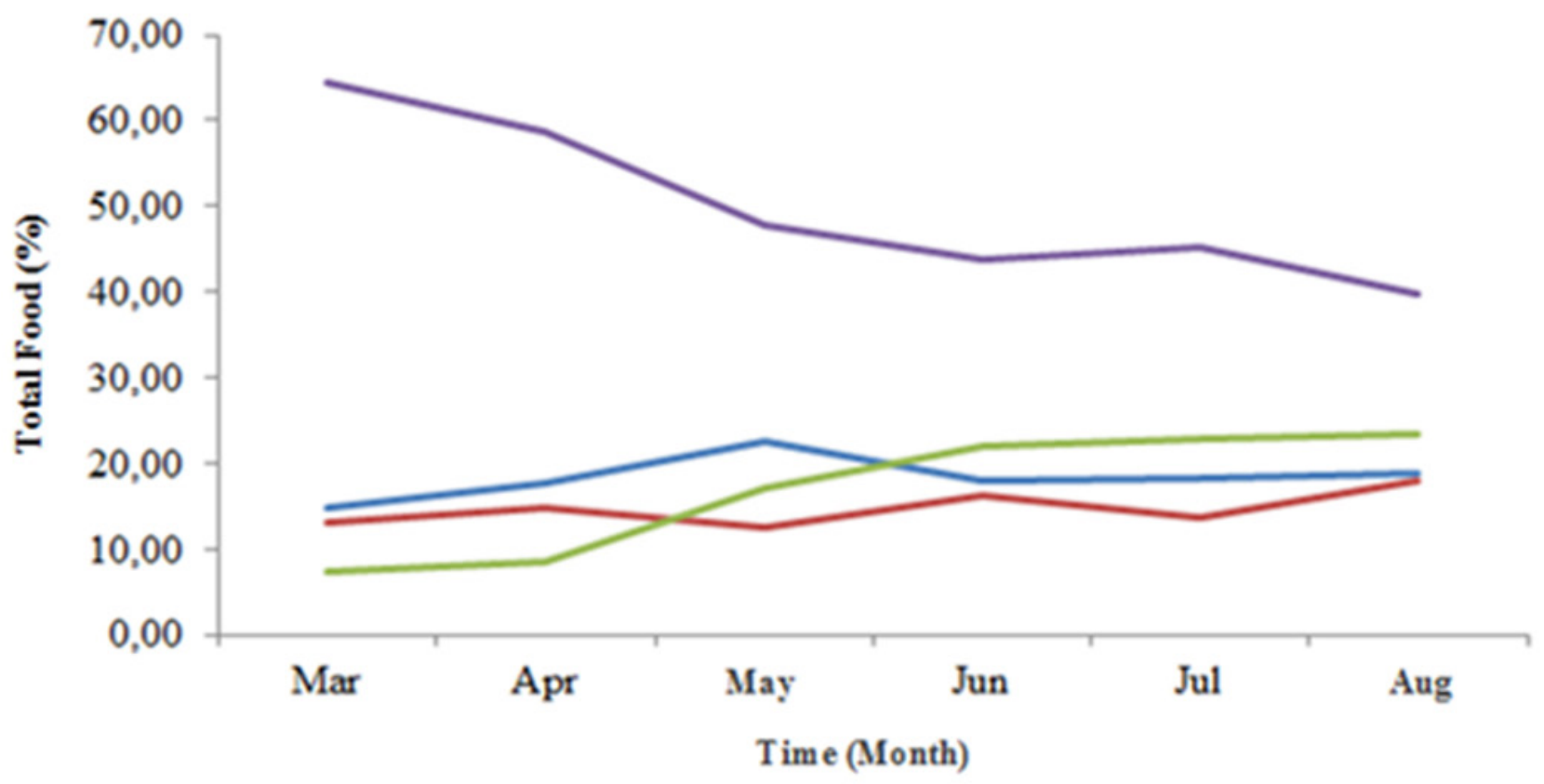

- Fish - Crustacean - Cephalopods Unidentified

Fig 4. Growth pattern of bullet tuna for female $(A)$ and male (B) 

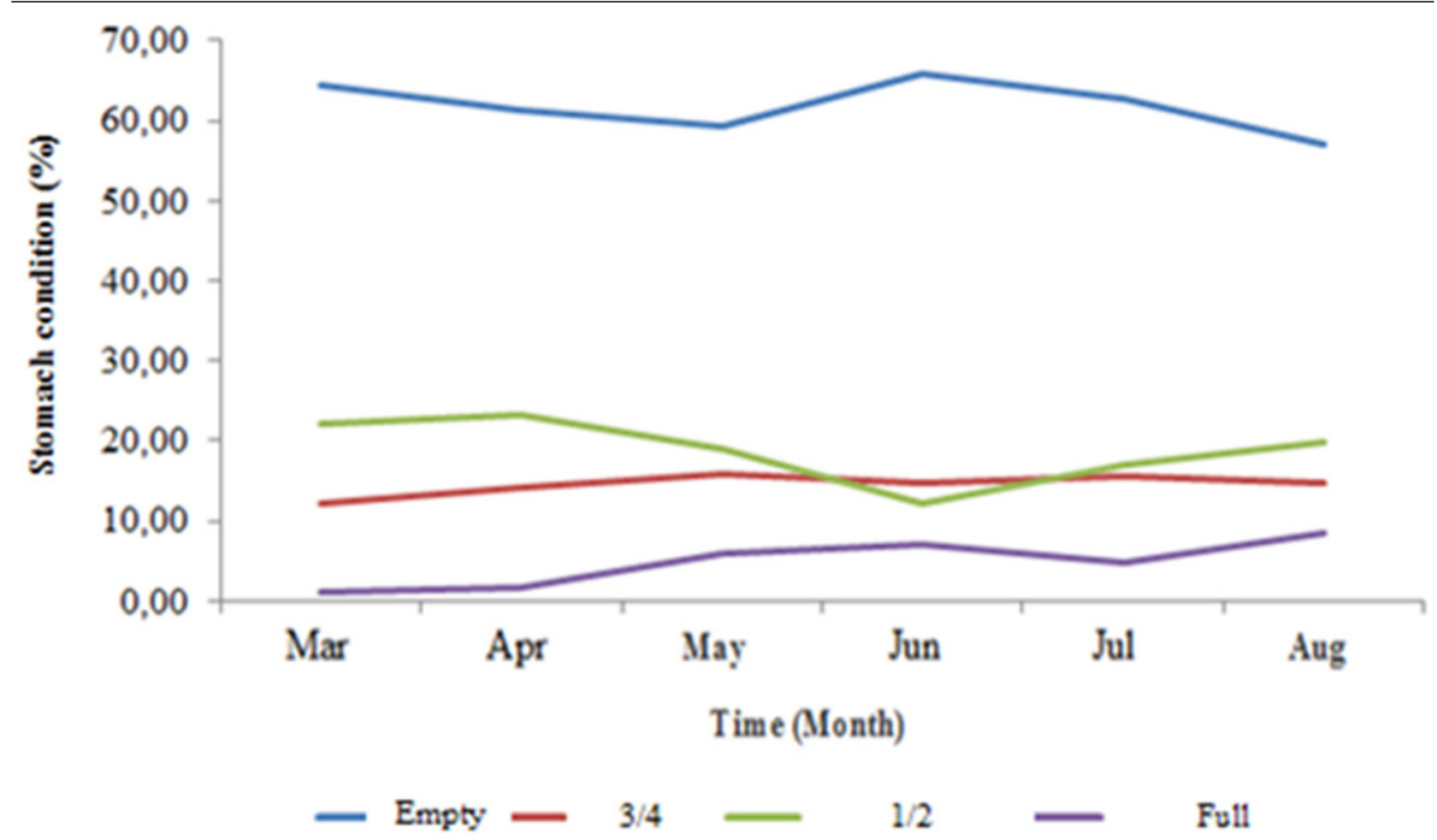

Fig 5. Level of stomach fullness of bullet tuna during the study period between March and August 2017

\section{DISCUSSION}

In the present study, the size distribution of the female bullet tuna was wider than of the male fish (Figure 2). However, this result differs from the size distribution found in Majene waters, the Makassar Strait which is narrower than the fish size distribution in Babana waters, central Mamuju (20.0-26.0 cm) (Kantun, 2016). Conversely, Kantun and Amir (2016) reported that the size distribution of bullet tuna found in Bone Bay was narrower $(41-42 \mathrm{~cm}$ or $14.60 \%)$. Several studies on size distribution of bullet tuna are the following: Gibraltar, $47 \mathrm{~cm}$ (Rodiguez-Roda, 1966); Turkey waters, 28.5-44.5 cm (Bok and Oray (2001); Spanish Mediterranean southwest 33.4-47 cm (Macias et al., 2005); Southeastern Mediterranean 25-47 cm (Macias et al., 2006; Pacitan waters, 22-28.2 cm (Prayitno et al., 2017).

The type and size of fishing rods, including fishing technology and biological nature lead to the difference in fish size distribution. The size of the fishing rod affects the composition and size of the fish caught because it is associated with mouth openings of the fish. On the other hand, fish tends to swim in schools of fish of identical length and weigh, thus contributing to the distribution of fish size.

The growth pattern of male (3.4934 with $r^{2}$ of 0.5922$)$ and female (3.246 with $r^{2}$ of 0.5142 ) bullet tuna was classified into a positive allometric pattern. In other words, the weight gain is faster than the length gain. If it is associated with the condition of resources in nature, then the level of utilization of tuna in Central Mamuju is still relatively low. Nonetheless, the growth pattern of female bullet tuna in May showed a negative allometric growth pattern. This is due to a decrease in body weight of female bullet tuna associated with the occurrence of gonadal maturity and spawning season in the following month during the study period.

Differences in the value of $b$ may occur between different populations of the same species or between the same population in different years related to biological and ecological conditions, such as the carrying capacity of the environment where the fish live. Changes in the environment and biological conditions of fish can cause changes in the relationship of long weights. These changes are caused by the condition of fish and they depend on food, age, sex and gonadal maturity.

Macias et al. (2006) reported that a positive allometric growth pattern $(b=3.292)$ of bullet tuna Auxis rochei was obtained in the Mediterranean waters of Western Spain. Plandri et al. (2009) obtained a positive allometric growth pattern $(b=3.674)$ in the Ligurian Sea. Noegoroho et al. (2013) reported negative allometry of bullet tuna ( $b=$ 2.933) in West Coast waters of Sumatra. Rodrigues-Roda (1966) reported positive allometry $(b=3.129)$ in Spanish waters. The differences in growth patterns (value b) are caused by fish behavior. Muchlisin (2010) argues that the size of $b$ value can be influenced by the behavior of fish, such as active swimming fish showing a lower value of $b$ when compared to fish that swim passively. This is related to the allocation of energy spent on movement 
and growth. In addition, the general value of $b$ depends on physiological and environmental conditions such as temperature, $\mathrm{pH}$, salinity, geographical location, sampling techniques (Jenning et al., 2001), and biological conditions such as gonadal development and food availability (Froese, 2006). Moreover, Fafioye and Oluajon (2005) argue that fish growth is generally relative in nature which can change according to time. If there is a change in the environment and the availability of food, the value of length and weight will also change (Garcia-Arteaga et al., 1997). These changes are influenced by genetics, sex, age, temperature and food availability to support their lives (Effendie, 2002).

The results of observations of the stomach indicated that the gut of bullet tuna was dominated by unidentified food ( $47.69 \%$ to $64.51 \%$ or average $\pm 56.1 \%$ ), cephalopods ( 7.32 to $34.80 \%$ or average $\pm 21.06 \%$ ), crustaceans 12.50 $25.64 \%$ (average $\pm 19.07 \%$ ) and fish species (14.98 to $22.9 \%$ or average $\pm 18.83 \%$ ), respectively. This is in line with Kumaran (1964) who determined 3 majors type of food for bullet tuna in the Indian Ocean. They are finfishes (Sardinella spp, Anchoviella spp, Leiognathus sp, and Carangidae), crustaceans (Rhopolophthalmus sp, Hyperia bengalensis, Oxycephalus Clausi, Pseudophausia latifrons, Acetes erythreus, Squilla larvae) and cephalopods. Noegroho et al. (2013) found the gut of bullet tuna in an empty condition (61\%), filled with anchovy Stolephorus sp (28\%) and unidentified fish (12\%) obtained from 175 fish. Ghosh et al. (2010) found that the type of food in bullet tuna includes Crustacea, Mollusca, Annelida, Anthyphyta and some small pelagic fish such as Stolephorus spp. Sardinella spp. and trevally fish species, whereas Froese and Pauly (2009), Kahraman et al. (2010), Widodo et al. (2012) found the type of food obtained from the gut of bullet tuna such as small fish, anchovy, crustacean and squids. Similarly, Mostarda et al. (2007) claimed that the bullet tuna of 194 and $465 \mathrm{~mm}$ (FL) in size is more likely to prey on fish larvae, planktonic invertebrates and smallsized cephalopods.

The types of food found in the stomach indicate that tuna are not classified as selective when searching for food. The unidentified type of food is due to the digestive process and the possibility that it had also been absorbed. The diversity of food types found in tuna was also an indicator of optimal water quality and food availability in the tuna fishing grounds. Interestingly, unidentified food tends to decline between May and August, during the study period. Decreasing the number of unidentified foods probably related to food absorption due to energy intake. A lot of energy intake is required during the gonadal maturation. In the present study, the highest spawning peak and gonadal maturity occurred in August. This suggests that the more fish gonads mature, the more food is needed to stimulate the development of gonadal hormones.

Noegroho et al. (2013) found that from 65 of Auxis thazard stomachs, the gut contained unidentified food $(41 \%)$, no food (32\%), sardines (Sardinella sp) (14\%), crustaceans
(Acetes spp) (10\%), anchovies (Stolephorus sp) (2\%) and squids (Lolingidae) (1\%). Furthermore, Noegroho et al. (2013) reported that out of 175 gut samples of bullet tuna Auxis rochei, empty stomach conditions were $61 \%$, containing $28 \%$ anchovies (Stolephorus sp) and $12 \%$ of unidentified food because they were shattered. In addition, in kawakawa Euthynnus affinis, with 54 stomach samples analysed, gut empty condition (83\%), unidentified fish (12\%) and $5 \%$ of scads (Decapterus sp) were found. The fullness of stomach was highly affected by the digestive process and food availability.

\section{CONCLUSION}

Variations in size distribution are caused by the size of the fishing rod, time of observation, fishing ground, fishing technology, cycle and the behavior of the fish. Growth patterns can be caused by fish behavior, physiological, biological conditions and food availability. The diversity of food types found in the stomach of tuna suggests the indicator of water quality and food availability in the fishing area. The condition of the stomach depends on the availability of food in nature, the duration of the digestion process and density of tuna population. Hand-line fishing gear for Auxis rochei bullet tuna fish promotes sustainable fish exploitation.

\section{ACKNOWLEDGMENTS}

We would like to thank The Ministry of Research, Technology \& Higher Education for funding this research through the National Strategy Research of Indonesia (PSNI) scheme.

\section{BIOLOŠKI ASPEKT TRUPCA Auxis rochei (Risso, 1810) U MAKASARSKOM TJESNACU, ZAPADNI SULAWESI, INDONEZIJA}

\section{SAŽETAK}

Ciljevi ove studije bili su utvrditi veličinu, rast, ishranu te indeks punoće želuca trupca Auxis rochei u tjesnacu Makassar, zapadni Sulawesi. Istraživanje je trajalo šest mjeseci u razdoblju od ožujka do kolovoza 2017. godine. Prikupljanje uzoraka provedeno je tehnikom ručnog ribolova udicom a ukupno je ulovljeno 2160 riba. Njihova totalna dužina (TL) je varirala od 15,8 do $28,5 \mathrm{~cm}$, a masa (W) od 52,3 do $366,5 \mathrm{~g}$. TL ženki kretala se u rasponu od 15,8 do $27,5 \mathrm{~cm}$, a W od 52,3 do 328,8 g. Dužinsko-maseni rast mužjaka i ženki trupaca bio je pozitivno alometričan (b>3); vrsta hrane koja se nalazila u probavnom sustavu sastojala se od rakova $(12,50 \%$ do $25,64 \%)$, glavonožaca (7,32 do $34,80 \%)$ i neidentificiranih organizama $(47,69$ do $64,51 \%)$. Unatoč tome, dominantna ishrana prema 
vrstama nije utvrđena, a u crijevima uglavnom nije pronađena hrana. Indeks punoće želuca kretao se u rasponu od punog $1,13 \%$ do $7,18 \%, 3 / 4$ ( 12,11 do $15,74 \%)$, $1 / 2$ (12,27 do $23,14 \%)$ i prazan $(59,26$ do $65,74 \%)$. Prema raspodjeli veličine, mužjaci trupca su bili veći od ženki s pozitivnim alometrijskim rastom, međutim bez utvrđene statistički značajne razlike.

Ključne riječi: rasprostranjenost, rast, ishrana, stanje crijeva, Auxis rochei, vode Mamuju

\section{REFERENCES}

Aswir, Z., Muchlisin, A., Ramadhani, I. (2004): Study on the fish food habits of skipjack Katsuwonus pelamis and frigate tuna Auxis thazard (English abstract). Jurnal Natural, 4, 20-23.

Bapal, S. V., Bal, D. V. (1958): Food of some young fishes from Bombay waters. Proceedings of Indian Academy Science, 35, 78-92.

Biswas, S. P. (1993): Manual of methods in fish biology. South Asian Publisher Private Limitide., New Delhi, 7991.

Bok, T., Oray I. K. (2001): Age and growth of bullet tuna Auxis rochei (Risso, 1810) in Turkish waters. ICCAT, Collect. Vol. Sci. Pap., 52, 708-718.

Effendie, M. I. (2002): Fish Biology. Yayasan Pustaka Nusatama. Yogyakarta. 163.

Fafioye, O., Oluajon, O. A. (2005): Length-Weight Relationships of Five Fish Species in Efe Lagoon. Nigeria, African. Journal of Biotechnology. 4, 7, 749-751.

Froese, R. (2006): Cube law, condition factor and weight length relationship: history, meta-analysis and recommendations. Journal of Applied Ichthyology, 22, 241-253.

Froese, R., Pauly, D. E. (2009): FishBase. FishBase Consortium, www.fishbase.org.

Garcia-Arteaga, J. P., Claro, R., Valle, S. (1997): Lengthweight Relationships of Cuban Marine Fishes. Naga, the ICLARM Quarterly, 20, 38-43.

Ghosh, S., Pillai, N. G. K., Dhokia, H. K. (2010): Fishery, population characteristics and yield estimates of coastal tunas at Veraval. Indian J Fish 57, 7-13.

Girsang, H. S. (2008): Study on determination of fishing ground for mackerel tuna through chlorophyll a mapping and capture production in Ratu Port, Jawa Barat.

Jenning, S., M. J. Kaiser, Reynolds, J. D. (2001): Marine Fishery Ecology. Blackwell Publishing Company Sciences, Oxford. 417.

Lubis, E., Pane, A. B. (2017): Institutional model of fish auction refunctionalization in Indonesian fishing ports. AACL Bioflux 10, 6, 1456-1465.

Kahraman, A .E, Göktürk, D., Rüstü Bozkurt, E., Akayli, T., Karakulak, F. S. (2010): Some reproductive aspects of female bullet tuna, Auxis rochei (Risso), from the Turkish Mediterranean coasts. African Journal of Biotechnology. 9, 40, 6813-6818.
Kantun, W. (2016): Capture Production and size distribution for Auxis rochei based on bait type, depth and capture time using hand-line in Majene Makassar Strait. Proceeding Semnaskan XIII UGM, 2016, 259-266.

Kantun, W., Amir, M. F. (2016): Biological aspects and capture compositions using hand-line techniques Bone Bay. Jurnal Balik Diwa. 7, 1-12.

Kaswadji, R., Hatta, M., Umar, N. A. (2009): Sustainable Fishing model of pelagic fish with the trophic approach in Makassar Strait. Jurnal Natur Indonesia 12, 67-74.

Kumaran, M. (1964): Studies on the food of Euthynnus affinis (Cantor), Auxis thazard (Lacepede) Auxis thynnoides Bleeker and Sarda orientalis (Temminck and Schlegel). In: Proceedings of the Symposium on Scombroid Fishes, Part 2; MBAl, 12-15 January 1962, Mandapam.

Macias, D., Gòmez, M. J., De la Serna, J. M. (2005): Some reproductive aspects of bullet tuna (Auxis rochei) from the south western spanish Mediterranean. ICCAT, Col. Vol. Sci. Pap. 58, 2, 484-495.

Macías, D., Lema, L., Gomez-Vives, M. J., Ortiz de Urbina, J. M., de la Serna, J. M. (2006): Some biological aspects of small tunas (Euthynnus alletteratus, Sarda sarda \& Auxis rochei) from the south western Spanish Mediterranean. ICCAT, Collect. Vol. Sci. Pap., 59, 2, 579589.

Mallawa, A., Najamuddin, M., Zainuddin, M., Abustang, S., Fakhrul, A. (2006): Stock assessment on fisheries and marine, Selayar Regency. Kantor Litbangda Kabupaten Selayar dengan Pusat Kajian Sumberdaya dan Wilayah Perairan Fakultas IImu Kelautan dan Perikanan Universitas Hasanuddin.

Melmambessy (2010): Stock assessment on bullet tuna Makassar Strait, South Sulawesi. Jurnal Ilmiah agribisnis dan Perikanan. 3, 1.

Muchlisin, A. (2010): Length-weight relationship and factors for three different fish species capture in the Kuala Gigieng water, Aceh Besar, Aceh province.

Mostarda, E., Campo, D., Castriota, L., Esposito, V., Scarabello, M., Andaloro, F. (2007): Feeding habits of the bullet tuna Auxis rochei in the southern Tyrrhenian Sea. Journal of the Marine Biological Association of the United Kingdom, 87, 4, 1007-1012.

Munira, (2010): Distribution and Stock of Rabbitfish Siganus canaliculatus in Seagrass, Lonthoir Strait, Banda Islands, Maluku. [Thesis]. School of Postgraduate, Bogor Agricultural University.

Noegroho, T., Hidayat, T., Amri, K. (2013): Some Biological Aspects of Frigate Tuna (Auxis thazard), Bullet Tuna (Auxis rochei), and Kawakawa (Euthynnus affinis) in West Coasts Sumatera IFMA 572, Eastern Indian Ocean. Third Working Party on Neritic Tunas, Bali, Indonesia. IOTC-2013-WPNT03-19. 1-13.

Piscandika, D., Efrizal, T., Zen, L. W. (2012): Potential and exploitation level of tuna (Euthynnus affinis dan Auxis thazard) Landing fish market in Desa Malang Rapat Kecamatan Gunung Kijang Kabupaten Bintan Provinsi 
Kepulauan Riau, Bintan Provinsi Kepulauan Riau

Plandri, G., Lanteri, L, Garibaldi, F., Orsi Relini, L. (2009): Biological Parameters of Bullet Tuna in the Ligurian sea. Collect. Vol. Sci. Pap. ICCAT. 64, 7, 2272-2279.

Prayitno, M. R. E., Simbolon, D., Yusfiandayani, R. (2017): Productivity of capture technology operated around deep FAD. Jurnal Marine Fisheries. 8, 1, 101-112.

Rodríguez-Roda, J. (1966): Study of Bacoreta, Euthynnus alletteratus (Raf.), bonito, Sarda sarda (Bloch) melva Auxis thazard (Lac.) caught in Almadrabas waters [in Spanish], Invest. Pesq. 30, 247-92.
Widodo, A. A., Satria, F., Barata, A. (2012): Catch and size distribution of bullet and frigate tuna caught by drifting gillnet in Indian Ocean based at Cilacap fishing PortIndonesia. IOTC-2012-WPNT02-12. 